\title{
Seroprevalence of Neospora infection in horses and donkeys in Hamedan province, Western I ran
}

\author{
Jamal Gharekhani ${ }^{1}$, Gholam-Reza Tavoosidana ${ }^{2}$ and Gholam-Reza Naderisefat ${ }^{3}$
}

1. Department of Parasitology, Central Veterinary Laboratory, I ranian Veterinary Organization, Hamedan, Iran. email: Gharekhani_76@yahoo.com ,Tel: +(98)811 2651801, Fax: +(98)811 2644474; 2. Department of Molecular Medicine, School of Advanced Technologies in Medicine, Tehran University of Medical Sciences, Tehran, Iran. email : Tavosi12@yahoo.com,Tel: +(98)21 88991118; 3. Department of Disease study, Iranian Veterinary Organization, Hamedan, Iran, email: Naderisefat@yahoo.com ,Tel: +(98)811 2651804

Corresponding Author: J. Gharekhani, email: Gharekhani_76@yahoo.com

Received: 26-01-2013, Revised: 14-03-2013, Accepted: 14-03-2013, Published online: 20-06-2013

\section{How to cite this article:}

Gharekhani J, Tavoosidana Gh.R and Naderisefat Gh.R (2013) Seroprevalence of Neospora infection in horses and donkeys in Hamedan province, Western I ran, Vet World 6(9): 620-622, doi: 10.5455/vetworld.2013.620-622

\begin{abstract}
Aim: The aim of the present study was to determine the seroprevalence of Neospora infection in horses and donkeys in Hamedan province, Western Iran.
\end{abstract}

Materials and Methods: In cross-sectional study, Blood samples ( $\mathrm{n}=220)$ were collected from 120 horses and 100 donkeys in 2012 year. All sera were screened for Neospora using Neospora modified direct agglutination test (N-MAT).

Results: Antibodies to Neospora infection in horses and donkeys were reported in $40.8 \%$ and $52 \%$, respectively. There was not significant correlation demonstrated between infection rates in different age groups and genders.

Conclusion: The current study is the first report of Neospora infection in donkeys from Iran. Further investigations and designing control strategies is recommended.

Key words: donkey, Hamedan, horse, Iran, Neospora, N-MAT,

\section{I ntroduction}

Neospora caninum with global distribution is a coccidian parasite that was first recognized in dogs from Norway in 1984 [1]. Wide range of animals such as cattle, sheep, horses and donkeys may be play the role of intermediate hosts for this parasite [2]. Another species of Neospora, N. hughesi is considered as equine parasite [2]. Neosporosis can cause abortion, protozoal myeloencephalitis and neuromuscular disorder signs in horse [3].

Several assays are available for detection of antibodies to $N$. caninum in animals [4]. Neospora Agglutination Test (NAT) is the most used serological method for Neospora detection in horses [5]. Some serological study of N.caninum infection in cattle [6], dog [7], water buffalo [8], camel [9], horse [10], and sheep [11], have done in different region of Iran. There is no published information on Neospora infection in equine of Hamedan.

The aim of this study was to determine the seroepidemiology of Neospora spp. in domestic equine (Horses and Donkeys) from Hamedan province, West of Iran.

\section{Materials and Methods}

Sampling: A cross-sectional study was performed during April to December 2012. Blood samples $(n=220)$

This article is an open access article licensed under the terms of the Creative Commons Attribution License (http://creativecommons. org/licenses/by/2.0) which permits unrestricted use, distribution and reproduction in any medium, provided the work is properly cited. were collected randomly from 120 horses (Equus caballus) $(37.5 \%$ in horse riding clubs, and $62.5 \%$ in rural horses), and 100 in donkeys (Equus africanus asinus) from different region of Hamedan province. Information about age and gender was taken from owners and physical examination was done. The animals were categorized into three age groups $(<3 \mathrm{yr}$, $3-6 \mathrm{yr}$ and $>6 \mathrm{yr}$ ).

Neospora modified direct agglutination test (N-MAT): All sera were removed after centrifugation at $1200 \times \mathrm{g}$ for $10 \mathrm{~min}$ and stored at $-20^{\circ} \mathrm{C}$ until laboratory examing. Anti-Neospora antibodies of samples were detected using the Neospora modified direct agglutination test (N-MAT) [12]. In brief, sera were doubling diluted from 1:10 to $1: 80$ with phosphatebuffered saline containing 0.2 M 2-mercaptoethanol, and $50 \mu \mathrm{l}$ of each dilution was put in a well of $96 \mathrm{U}-$ bottom microtiter plates. Then, $50 \mu \mathrm{l}$ of $3.5 \times 10^{7} / \mathrm{ml}$ tachyzoites suspension (NC-1 strain of $N$. caninum) resuspended in alkaline buffer $(7.02 \mathrm{~g}$ of $\mathrm{NaCl}, 3.09 \mathrm{~g}$ of $\mathrm{H} 3 \mathrm{BO} 3,24 \mathrm{ml}$ of $1 \mathrm{~N} \mathrm{NaOH}, 4 \mathrm{~g}$ of horse serum albumin [fraction V], $50 \mathrm{mg}$ of eosin $\mathrm{Y}, \mathrm{dH} 2 \mathrm{O}$ to 1 liter, $0.1 \%$ sodium azide as a preservative; $\mathrm{pH}: 8.7$ ) were added to each serum dilution of samples as well as positive and negative controls. The wells were then mixed thoroughly by pipetting up and down several times; covered, and incubated overnight at $37^{\circ} \mathrm{C}$ with $5 \% \mathrm{CO}_{2}$. A cut-off titer of 1:80 was considered as significant for the presence of antibodies [13]. when the tachyzoites were spread on entire bottom of micro plate wells, and those showing button formation were 
Table-1. Seroprevalence of Neospora sp. in different gender and age groups in horses and donkeys from western I ran.

\begin{tabular}{|c|c|c|c|c|c|}
\hline \multirow[t]{2}{*}{ Parameters } & \multicolumn{3}{|c|}{ Horse } & \multirow[t]{2}{*}{ Donkey } & \multirow[t]{2}{*}{ Total } \\
\hline & Riding club & Rural & Total & & \\
\hline \multicolumn{6}{|l|}{$\overline{\text { Sex }}$} \\
\hline Male & $26(57.9 \%)$ & $17(52.9 \%)$ & $43(46.5 \%)$ & $22(36.1 \%)$ & $65(43 \%)$ \\
\hline \multicolumn{6}{|c|}{ Age groups (year) } \\
\hline$<3$ & $3(0 \%)$ & $53(45.3 \%)$ & $56(42.8 \%)$ & $77(51.9 \%)$ & $133(48.1 \%)$ \\
\hline $3-6$ & $40(47.5 \%)$ & $20(30 \%)$ & $60(41.7 \%)$ & $23(52.2 \%)$ & $83(44.6 \%)$ \\
\hline$>6$ & $2(0 \%)$ & $2(0 \%)$ & $4(0 \%)$ & $0(0 \%)$ & $4(0 \%)$ \\
\hline Total & $45(42.2 \%)$ & $75(40 \%)$ & $120(40.8 \%)$ & $100(52 \%)$ & $220(45.9 \%)$ \\
\hline
\end{tabular}

Figures in bracket shows positive no.

considered positive and negative, respectively.

Study area: Hamedan province by mountainous and mild climate is located in west part of Iran $\left(34.77^{\circ} \mathrm{N}\right.$ and $48.58^{\circ} \mathrm{E}$ ). This region is economically impressed by an agricultural and animal husbandry. According to veterinary office report of 2010, the equine population in this area was approximately 22,000.

Statistical analysis: Statistical analysis was performed by using the software package SPSS version 16.0 for windows. The differences among variables were evaluated by $C h i$-square test. $P$-value of less than 0.05 was considered statistically significant.

\section{Results}

The frequency of prevalence for Neospora antibodies was shown as much as $45.9 \%$ (95\% CI: $43.9 \%-48 \%$ ) (Table-1). Seroprevalence of Neospora in horses and donkeys were found in $40.8 \%$ (95\% CI: $34.77 \%-46.83 \%)$ and $52 \%$ (95\% CI: $42.01 \%-61.99 \%)$, respectively $\left(\chi^{2}=2.738, \mathrm{P}=0.098\right)$. In horses, seroprevalence rate of riding club samples $(42.2 \%)$ was higher than rural samples $(40 \%)\left(\chi^{2}=0.057, \mathrm{P}=0.811\right)$. The most and least frequency rates were shown in equines $<3 \mathrm{yr}(48.1 \%)$, and $>6 \mathrm{yr}(0 \%)$, respectively. Furthermore, there was not found statistical differences among age groups $\left(\chi^{2}=0.570, P=0.752\right)$ and genders $\left(\chi^{2}=0.298, P=0.585\right)$.

\section{Discussion}

As per our knowledge, this study is the first report of Neospora seroprevalence in donkeys from Hamedan province, West of Iran.

The seroprevalence rate of Neospora was reported from zero to $77.7 \%$ in horses worldwide [1]. The previous serological studies in Neospora sp. in horses were reported $28 \%$ in Northwest, $30 \%$ in Northeast, and $32 \%$ in South of Iran $[10,12,13]$. In the present study, Neospora seroprevalence in horses $(40.8 \%)$ was obtained similar to investigation from Southern Brazil [14]. The prevalence rate in riding club samples was higher than rural samples, due to intensive system and their direct contact by dogs inside the club. Neurological signs and abortion history were not showed in any samples, similar to our results. Different serological assays, study design, and geographical conditions are main cause of varied results.

In current study, there was no statistical significant between the seroprevalence samples and different gender, as similar to other investigations $[5,10,12,13,15,16,17]$.

There are both way (horizontal and vertical) transmission of Neospora in animals [1,2]. After the confirmation of the $\mathrm{dog}$ as a definitive host, the presence of dogs in farm has been assumed to provide the greatest chance of horizontal transmission through the ingestion of oocysts, shed by infected dogs [1].

Our results and Gharekhani [6] study in cattle from Hamedan indicate that exposure to Neospora is common in West of Iran, and the horizontal way is a major mode of transmission in equine from this region. The results of this survey can provide baseline information for the future investigations. However, comprehensive studies in other Neospora hosts and a further molecular characterization of extracted DNA, and isolation of parasites by bioassay examination is necessary.

\section{Conclusion}

The current study is the first report of Neospora seroprevalence in donkeys from Iran. The seroprevalence of Neospora in horse is reported in some region of Iran, before our study. Therefore further investigations and designing control strategies is highly recommended, since donkeys may be play significant role in the wild animal (Coyotes and Foxes) infection. In Iran, The donkeys living outdoor, therefore maybe eaten by wild animals and complete the life cycle.

\section{Authors' contributions}

JG: project manager and designer, sampling and testing. GRT: technical guidance. GRN: carried out the statistical analysis. All authors drafted an revised the manuscript. All authors read and approved the final manuscript.

\section{Acknowledgements}

We greatly appreciate Dr. Alireza Salehi and Dr. Aliasghar bahari for technical guidance. This study was done with own fund and interest of authors and no outside fund was received for this study.

\section{Competing interests}

The authors declare that they have no competing interests.

\section{References}

1. Dubey, J.P., Schares, G. and Ortegamora, L.M. (2007) Epidemiology and control of Neosporosis and N. caninum, Clinic. Rev, 20:323-369. 
2. Dubey, J.P. and Schares, G. (2011) Neosporosis in animalsThe last five years, Vet. Parasitol, 180:90-108.

3. Carrie, J., Monica, A. and Nicola, P. (2007) Equine protozoal myeloencephalitis associated with Neosporosis in 3 horses, J. Vet. Intern. Med, 21:1405-1408.

4. Nourollahi-fard, S.R., Khalili, M. and Aminzadeh A. (2008) Prevalence of antibodies to N.caninum in cattle in kerman province, South East Iran, Vet. Archiv, 78(3):253-259.

5. Pitel, P.H., Romand, S., Pronost, S., Foucher, N., Gargala, G., Maillard, K., Thulleiz, P., Collobert, C., Taintureir, D., Fortier, G. and Ballet, J.J. (2003) Investigation of Neospora spp. Antibodies in aborted mares from Normandy, France, Vet. Parasitol, 118:1-6.

6. Gharekhani, J., Heidari, H. and Akbarein, H. (2012) Seroepidemiology of Neospora caninum in Iranian native and crossbreed cattle: A cross sectional study, J. Vet. Res, 67(4): 325-329.

7. Malmasi, A., Hosseininejad, M., Haddadzadeh, H. Badii, A. and Bahonar, A. (2007) Serologic study of anti-Neospora caninum antibodies in household dogs and dogs living in dairy and beef cattle farms in Tehran, Iran, Parasitol. Res, 100:1143-1145.

8. Hajikolaei, M.R.H., Goraninejad, S., Hamidinejat, H., Ghorbanpour, M. and Paryab, R. (2007) Occurrence of N.caninum antibodies in water buffaloes (Bubalus bulalis) from the South-Westhern region of Iran, Bull. Vet. Inst. Pulawy, 51:233-235.

9. Sadrebazzaz, A., Haddadzadeh, H.R. and Shayan, P. (2006) Seroprevalence of Neospora caninum and Toxoplasma gondii in camels (Camelus dromedarius) in Mashhad, Iran, Parasitol. Res, 98:600-601.
10. Hosseini, M.H., Moraveji, M., Tahamtan, Y., Rahimian, A., Mohammadi, G.H. and Namavari, M.M. (2011) Seroprevalence of Neospora spp. in horses in Northeast of Iran, Iranian. J. Parasitol, 6(2):64-68.

11. Ezatpour, B., Alirezaei, M., Hassanvand, A., Zibaei, M. and Azadpour, M. (2013) The first report of Neospora caninum prevalence in aborted and healthy sheep from west of Iran Comparative Clinical Pathology 1-4.

12. Moraveji, M., Hosseini, M.H., Amrabadi, O., Rahimian, A., Namazi, F. and Namavari, M. (2011) Seroprevalence of Neospora spp. in horses in South of Iran, Trop. Biomed, 28(3):514-517.

13. Gharedaghi, Y. (2012) Seroprevalence of Neospora sp. in horses in East-Azerbaijan Province of Iran, J. Anim. Vet. $A d v, 11(4): 480-482$.

14. Locatelli, R., Dittrich, R., Richartz, R., Gasino, M.E., Antunes, R.D., Pinckney, I., Deconto, D.C., Hoffmann, S. and Thomaz, V. (2006) Investigation of Neospora Sp. And Toxoplasma gondii antibodies in mares and in precolostral foals from Parana State, Southern Brazil, Vet. Parasitol, 135:215-221.

15. Dubey, J.P., Venturini, M.C., Venturini, L., Mc-Kinney, J. and Pecoraro, M. (1999) Prevalence of antibodies to Sarcosystis neurona, Toxoplasma gondii, and Neospora caninum in horses from Argentina, Vet. Parasitol, 86:59-62.

16. Jakubek, E.B., Lunden, A. and Uggla, A. (2006) Seroprevalences in Toxoplasma gondii and Neospora sp. Infections in Swedish horses, Vet. Parasitol, 138:194-199.

17. McDole, M.G. and Gay, J.M. (2002) Seroprevalence of antibodies against Neospora caninum in diagnostic equine serum samples and their possible association with fetal loss, Vet. Parasitol, 105:257-260. 